\title{
Table of Contents
}

Manja Kisner and Jörg Noller

Introduction — 1

\section{Part I Kant's Conception of Will}

Sorin Baiasu

Free Will and Determinism: A Solution to the Kantian Paradox -7

Markus Kohl

Spontaneity and Contingency: Kant's Two Models of Rational

Self-Determination -29

Halla Kim

How is the Corruption of the Will Possible? Kant on Natural Dialectic and Radical Evil -49

Günter Zöller

Eleutheronomy: Will, Law and Liberty in Kant's Esoterically Political Philosophy 71

\section{Part II The Concept of Will after Kant}

John Walsh

The Fact of Freedom: Reinhold's Theory of Free Will Reconsidered - 89

Amit Kravitz

On the Real Possibility of a Pure Moral Will: Maimon vs. Kant -105

Tom Giesbers

Drive as a Constitutive Element of Practical Action in Jacobi and Fichte 125

Manja Kisner

Drive and Will in Fichte's System of Ethics — 139 
VI - Table of Contents

Ansgar Lyssy

Reality as Resistance: The Concept of the Will in Bouterwek's Idea of an Apodictic (1799) - 159

Jörg Noller

“Will is Primal Being": Schelling's Critical Voluntarism — 181

Daniel Wenz

Hegel's Logical Foundation of the Will: Reconciling Psychology and Social-Ontology 203

Alex Englander

Hegel and the Paradox of Willkür -227

Jenny Bunker

Ethics and Will in Schopenhauer's Philosophy — 247

Index of Names -263

Index of Subjects - 265

Notes on Contributors -269 